Topçuoğlu Ünal, F. ve Sevimli, F. (2014) Şiir okuma performansını değerlendirme ile ilgili görüşler ve bir değerlendirme formu önerisi. Ana Dili Eğitimi Dergisi. 2(1), 96-112.

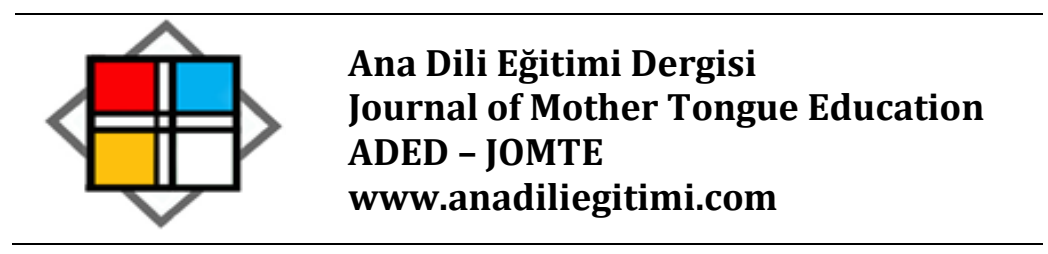

\title{
Şiir Okuma Performansını Değerlendirme ile ilgili Görüşler ve Bir Değerlendirme Formu Önerisi
}

\author{
Fulya Topçuoğlu Ünal ${ }^{1}$ \\ Fatih Sevimli $^{2}$
}

\section{Özet}

Dünya ve Türk edebiyatında yeri çok eskilere dayanan şiir, öğrencilerin dil becerilerinin gelişmesine, bununla birlikte öğrencilerin kendilerini daha rahat bir şekilde ifade edebilmelerine yardımcı olmaktadır. Araştırmanın genel amacı, şiir okuma performansını değerlendirme ile ilgili görüşleri belirlemek ve bir değerlendirme formu önerisinde bulunmaktır. Araştırma nitel araştırma yöntemlerinden görüşme yöntemiyle gerçekleştirilmiştir. Araştırmanın çalışma grubu, Kütahya'daki kamu ilk ve ortaokullarında görev yapan 16 öğretmen, 5 öğretmen adayı ve 2 öğretim üyesinden oluşmuştur. Veriler yarı yapılandırıımış görüşme yöntemi ile toplanmıştır. Çalışmanın sonucunda görüşmelerden elde edilen verilerle şiir okumada bir standarda gidilebilmesi için "Şiir Okuma Performansını Değerlendirme Formu" oluşturulmuştur. Formda iyi şiir okunabilmesi için "ses, beden dili, duygu, dinleyici, ortam" boyutları ve bu boyutlara göre tespit edilmiş 43 madde yer almaktadır.

Anahtar kelimeler: Şiir, şiir okuma, değerlendirme, şiir okuma performansı, form.

\section{The Opinions Related with Assessing Poem Reading Performance and an Assessment Form Suggestion}

\begin{abstract}
The poem whose place is based on ancient times in the World and Turkish literature helps to improve students' language skills; at the same time it helps students to express themselves more comfortable. The purpose of this study is to identify the opinions related with assessing poem reading performance and to suggest an assessment form. As one of the qualitative research methods, the interview method was used in this study. The participants of the study were 16 teachers from public primary and secondary schools, 5 pre-service teachers and 2 lecturers from a university. The data were collected with semi-structured interviews. "Poem Reading
\end{abstract}

\footnotetext{
${ }^{1}$ Yrd. Doç. Dr. Dumlupınar Üniversitesi, Eğitim Fakültesi, Türkçe Eğitimi Bölümü. Kütahya. e-posta: fulyatopcuoglu@gmail.com

${ }^{2}$ Yüksek Lisans Öğrencisi, Dumlupınar Üniversitesi, Eğitim Bilimleri Enstitüsü, Türkçe Eğitimi ABD. Kütahya. e-posta: fatihsevimli85@hotmail.com
} 
Performance Assessment Form" was formed as a result of these interviews for a standardized poem reading. In this assessment form there were 43 items at the dimensions of "voice, body language, emotion, audience, environment" for a good poem reading performance.

Keywords: Poem, poem reading, assesment, poem reading performance, form

\section{Giriş}

Şiir, edebiyatın en önemli ve insanları en çok etkileyen türlerinden biridir. Insanlar, tarihi çağlar başlamadan önce -yazı kullanılmadan- şiirler okumuşlar, dertlerini ve umutlarını şiirlerle dillendirmişlerdir.

Insanların duygu ve düşüncelerini estetik bir biçimde ortaya koydukları şiirin, günümüze kadar birçok tanımı yapılmıştır. Şiir, genellikle en az sözcükle en çok şey anlatma sanatı olarak tanımlanır; ancak güzel sanatların bir kolu olarak şiirde, düz anlatımın yanında belli biçimsel kurallara uyma, sözcük seçimi, iç ve dış uyumun yanında estetik bir kaygı da söz konusudur (Kıbrıs, 2000). Kaplan (2003)'a göre şiir, edebiyat nev'ileri içinde sözün manasını edebî sanatlar yoluyla en fazla gözleyen yazı türüdür. Şiiri, zengin hayallere, sembolik ve imaja dayalı anlatımlarla, ritimli sözlerle, seslerin uyumlu kullanımıyla ortaya çıkan edebiyat türü diye de tanımlayabiliriz. Şiirde günlük dilin kelimelerine özel anlamlar yüklenir. Duygu, düşünce ve izlenimler bir takım hayallere, sembollere, söz sanatlarına başvurularak anlatılır (Kavcar ve Oğuzkan, 1999).

Şiirin, söze diğer edebî türlerden daha hâkim olduğu da bilinen bir gerçektir. Şiir okuyan, daha doğrusu şiiri etkili okuyan bireylerin hitabeti de güçlüdür. Bu bireyler hitabet ve sözü güzel söyleme yeteneğiyle karşılarındaki insanları daha çok etkileyebilirler. Güzel şiir okumanın ne olduğunu Kıbrıs (2008: 57) "şiirin yansıtmak istediği duyguyu yaşayarak, dinleyenlerde de aynı duyguları uyandırmak amacıyla yapılan okuma" şeklinde açıklamaktadır. Ayrıca güzel şiir okumanın okunan şiirin dinleyenlerce daha çok sevilmesini sağladığını, güzel okunan bir şiirin hem okuyan hem de dinleyen üzerinde daha etkili olduğunu eklemektedir.

Şiir; etkili, güzel ve doğru dil kullanımına katkı sağlamaktadır. Şiir dil becerilerinin gelişmesine katkıda bulunmakla birlikte öğrencilerin kendilerini daha rahat bir şekilde ifade edebilmelerine yardımcı olmaktadır. Öğrencilerin Türkçe dersi ile Türkçeyi doğru, güzel ve etkili kullanması hedeflenmektedir. Ana dili programlarında 1. ve 2. kademelerde yer alan Türkçe derslerinde 1.sınıftan başlamak üzere 10'u aşkın kazanım yer almaktadır. Bu kazanımlar genel olarak şiir yazma, dinleme ve ana fikri anlama becerileri üzerine yoğunlaşmıştır. Türkiye'de birinci ve ikinci kademede uygulanmakta olan Türkçe öğretim programlarına baktığımızda yer verilen amaçları gerçekleştirilebilmenin de nitelikli, düzeye uygun, programın amaçlarıyla örtüşen, türünün özelliklerini yansıtan şiirlerin kullanılmasıyla olanaklı olacağı açıkça görülebilir (WEB1). 
Şiirin çok önemli bir yerinin olduğu, Türkçe öğretim programlarının yanı sıra kutlama programları, şiir dinletileri gibi daha birçok etkinliklerde de görülmektedir. Dilin bütün alanlarına hitap eden şiirin, okuma yazma öğretiminde de çok önemli bir yeri vardır. İlk okuma-yazma öğretiminde şiir; kelime öğretimini, sesi kullanmayı, sese noktalama ve vurguyu vermeyi, akıcılığı ve çocuğun sözlü ifade gücünü geliştirir (Kaya, 2013). Şiirde bulunan ritim, ses, kafiye ve ses yinelemeleri, şiiri okuyan ve dinleyen insanlarda estetik zevk uyandırmaktadır. Şiiri düz yazıdan ayıran bu özellikler, şiirin doğru okunmasıyla ortaya çıkmaktadır. Şiir okumak (inşat) bir sanattır. Bir şiiri güzel okuyabilmek için, önce onu doğru seslendirmek gerekir. Şiiri doğru okumak ise işin tekniğine ait bir takım bilgileri gerektirir. Bu teknik bilgiler kişinin şiir okuma performansını gösterir.

Performans, bir hedefe ulaşma, amacı gerçekleştirme düzeyidir. Hedefin ne kadarına ulaşılıp ulaşılmadığı şeklinde de ifade edilir. Bayram (2006: 48)'a göre performans, "belirlenen koşullara göre bir işin yerine getirilme düzeyi ya da bir iş görenin belirli zaman kesiti içerisinde kendine verilen görevi yerine getirmek suretiyle elde ettiği sonuçlardır". Ortada bir performans olduğu zaman beraberinde bu performansın ne derece gerçekleştiğini belirlemek için performans değerlendirme söz konusudur. Performans değerlendirme ise; "öğrencilerin bireysel özellikleri dikkate alınarak, bunları uygulamaya dönüştürmelerini sağlayacak durum ve ödevler" olarak tanımlanabilir (Özbay, 2007: 167).

Değerlendirme, klasik (geleneksel) ve çağdaş ölçme ve değerlendirme olarak ikiye ayrılmaktadır. Geleneksel ölçme ve değerlendirme, kalabalık sınıflarda çok kısa bir zaman diliminde uygulanan genellikle yazılı yoklama, sözlü yoklama, çoktan seçmeli test, doğru-yanlış soruları, kısa cevaplı sorular ve eşleştirme sorularının kullanıldığı bir uygulamadır. Öğrenci başarısını yansıtmaması, üst düzey zihinsel becerileri geliştirmede yetersiz kalması, ezberciliğe itmesi ve kısa zamanda uygulanması gibi dezavantajları vardır. Klasik değerlendirme türleri, günümüz eğitim felsefeleri ve sistemlerinin değişmesiyle birlikte eski önemini yitirmiştir. Ülkemizde ilköğretimde 2005, ortaöğretimde ise 2006 yıllarında uygulamaya koyulan yapılandırmacı eğitim sisteminde çağdaş değerlendirme esas alınmıştır. Çağdaş ölçme ve değerlendirmenin portfolyo (tümel), performans değerlendirme, öz değerlendirme, akran değerlendirme, gibi türleri bulunmaktadır (Özçelik, 2010). Yeni öğretim yaklaşımlarında ölçme ve değerlendirme, öğrencilerin neyi bilmediğini değil, neyi bildiklerini belirlemeye yarayan bir süreç olarak görülmektedir (MEB, 2005).

Çağdaş ölçme ve değerlendirme anlayışı, öğrenciyi merkeze almış ve öğrenciye performansını açıkça gösterme fırsatı sunmuştur. Alternatif ölçme ve değerlendirme, tek bir doğru cevabı olan çoktan seçmeli testlerin de içinde bulunduğu geleneksel değerlendirme dairesinin dışında kalan tüm değerlendirmeleri kapsar (Bahar, Nartgün, Durmuş ve Bıçak, 2008).

Yapılan alan incelemelerinde, şiir okuma performansını değerlendirmeye yönelik doğrudan herhangi bir çalışmaya rastlanmamıştır. Şiir okumanın değerlendirilmesinin standart bir hale 
getirilemediği tespit edilmiştir. Buradan hareketle böyle bir çalışma yapılmaya karar verilmiştir. Bu çalışmanın şiir okuma alanında bir boşluğu doldurabileceği düşünülmektedir.

Araştırmanın genel amacı, şiir okuma performansına yönelik görüşleri belirlemek ve bir değerlendirme formu ortaya koymaktır. Bu amaçla aşağıdaki sorulara cevap aranmıştır:

1. Şiir okuma performansını değerlendirmeye yönelik Türkçe Eğitimi alanında çalışan öğretim üyelerinin, öğretmenlerin, öğretmen adaylarının ve yüksek lisans öğrencilerinin görüşleri nelerdir?

2. Şiir okuma performansının değerlendirilebilmesi ve şiir okumada standarda gidilebilmesi için bir değerlendirme formu sunulabilir mi?

\section{Yöntem}

Bu çalışmada nitel araştırma tekniği kullanılmıştır. Çünkü nitel araştırmalar, araştırma yapılan ya da yapılması planlanan kişilerin sahip oldukları deneyimlerinden doğan anlamların sistematik olarak incelenebilmesinde tercih edilen bir tekniktir (Ekiz, 2003). Nitel araştırma tekniklerinin doğal ortama duyarlılık sağlaması, araştırmacının katılımcı rolü olması, bütüncül bir yaklaşıma sahip olması, algıların ortaya konmasını sağlaması, araştırma deseninde esnekliği olması ve tümevarımcı bir analize sahip olması önemli özellikleridir (Yıldırım ve Şimşek, 2011). Bu bağlamda nitel araştırmalar, araştırmanın üretildiği sosyal bağlama duyarlılığı sağlamaktadır (Kuş, 2003).

\section{Araştırma Grubu}

Araştırmanın çalışma grubunu, Türkçe alanında 2 öğretim üyesi, Türkçe alanında yüksek lisans yapan 3 öğrenci, Mili Eğitim Bakanlığında görev yapan 7 Türkçe öğretmeni, 2 Türk Dili ve Edebiyatı öğretmeni, 2 müzik öğretmeni, 5 sınıf öğretmeni ve 5 Türkçe öğretmen adayı olmak üzere toplam 26 kişi oluşturmaktadır.

Araştırma katılımcıları nitel araştırma yaklaşımı içinde yer alan amaçı̈ı örnekleme tekniklerinden ölçüt örnekleme tekniği ile belirlenmiştir. Amaçlı örnekleme zengin bilgiye sahip olduğu düşünülen durumların derinlemesine çalışılmasına olanak vermektedir (Yıldırım ve Şimşek, 2011). Bu örneklemede seçim için önemli olduğu düşünülen ölçütler belirlenmekte ve bu ölçütlere göre seçilen örneklemin, araştırma evrenini bütün nitelikleri ile temsil edebildiği düşünülmektedir (Tavşancıl ve Aslan, 2001). Bundan dolayı, çalışmada, amaca uygun bir örnekleme yoluna gidilmiştir. Bu örnekleme tekniğindeki temel anlayış, önceden belirlenmiş bir dizi ölçütü karşılayan bütün durumların çalışılmasıdır. Burada sözü edilen ölçüt veya ölçütler araştırmacı tarafından oluşturulabilir ya da daha önceden hazırlanan bir ölçüt listesi kullanılabilir (Yıldırım ve Şimşek, 2011).

Katılımcılar belirlenmeden önce araştırmacılar tarafından bir ölçüt listesi oluşturulmuştur. Ölçüt listesinde; Kütahya ilinde görev yapıyor olmak, görüş ve önerilerini açıklamak için istekli olmak, görüşmeler için gerekebilecek azami süreyi ayırabileceğini beyan etmek şeklinde kriterler 
bulunmaktadır. Araştırmaya katılan katılımcıların gönüllü olmaları araştırmanın geçerliği ve güvenirliğinin sağlanması açısından büyük önem taşımaktadır (Yıldırım ve Şimşek, 2011). Bu nedenle, katılımcıların görüşmelere gönüllü olarak katılmalarını sağlamak amacıyla araştırmacı görüşmelerden önce katılımcılara araştırmanın önemini belirten konuşmalar yapmıştır.

Görüşme yapılan öğretim üyeleri, Dumlupınar Üniversitesi Eğitim Fakültesi Türkçe Eğitimi Bölümünde; öğretmenler Kütahya il merkezinde ve Kütahya/Tavşanlı ilçesinde çalışmakta; yüksek lisans öğrencileri Dumlupınar Üniversitesi Eğitim Fakültesinin Türkçe Eğitimi Bölümünde yüksek lisans yapmakta ve öğretmen adayları ise yine Dumlupınar Üniversitesi Eğitim Fakültesinin Türkçe Eğitimi Bölümünün dördüncü sınıfında okumaktadırlar.

Çalışma grubu seçilirken şiir çalışmalarıyla doğrudan ilgilenen branşlar dikkate alınmıştır. Araştırmaya katılan öğretmenlerin 7'si üst sosyoekonomik düzeye sahip öğrencilerin devam ettiği okullarda, 9'u orta sosyoekonomik düzeye sahip öğrencilerin devam ettiği okullarda, 5 'i ise alt sosyoekonomik düzeye sahip öğrencilerin devam ettiği okullarda görev yapmaktadırlar.

\section{Verilerin Toplanması}

$\mathrm{Bu}$ araştırmada nitel araştırmada kullanılan veri toplama tekniklerinden birisi olan görüşme tekniği uygulanmıştır. Görüşme, sosyal bilimler alanında yapılan çalışmalarda en sık kullanılan veri toplama yöntemidir (Yıldırım ve Şimşek, 2011). Görüşmeler yarı-yapılandııılmış görüşme tekniği ile yapılmıştır. Bu yöntem ne tam yapılandırılmış görüşmeler kadar katı ne de yapılandırılmamış görüşmeler kadar esnektir; iki uç arasında yer almaktadır (Karasar, 2010). "Yarı yapılandırılmış görüşmenin; analizlerin kolaylığı, görüşülene kendini ifade etme imkânı, gerektiğinde derinlemesine bilgi sağlama gibi avantajları vardır" (Büyüköztürk, Çakmak, Akgün, Karadeniz ve Demirel, 2010: 163).

Şiir okuma performansını değerlendirme formu oluşturulması sırasında öncelikle performans kavramı seçilmiştir. Çalışmanın performans kavramı "şiir"dir. İkinci olarak performansın boyutları göz önüne alınarak buna yönelik sorular hazırlanmıştır. Üçüncü olarak performans düzeyleri oluşturulmuş, iyi şiir okuma için "yeterli, geliştirilmeli ve yetersiz" olarak sıralanmıştır. Değerlendirmenin kolay yapılabilmesi için düzeyler 3'ten fazlaya çıkartılmamıştır. Son olarak performans tanımları olan, iyi şiir okunmasında belirlenen tanım cümleleri yapılan görüşmelerden elde edilen bulgularla boyutlara yerleştirilmiştir. Bu tanım cümleleri yazılırken değer yargısı taşımamasına, gözlemlenebilir olmasına, anlatımının açık olmasına ve olabildiğince az sözcükle anlatılmaya çalışıımasına özen gösterilmiştir. Çalışmanın değerlendirme formu şeklinde düzenlenmesinin sebebi; ölçülecek performansın çok boyutlu olması, boyutlarının derecelendirilmesinin kolay olması, boyut ve düzeylerinin gözlemlenebilir olması ve değerlendirmede kullanılacak sürenin yeterli olmasındandır (Sezer, 2005). 
Araştırmada çalışma grubunun görüşlerini almak için araştırmacılar tarafından hazırlanan açık uçlu sorular kullanılmıştır. Soruların hazırlanması aşamasında literatür taranmıştır ve üç uzmanın görüşüne sunulmuştur. Uzmanlarla yapılan ön görüşmelerde, araştırma grubuna sorulacak soruların anlaşılır olma, ele alınan konuyu kapsama ve gerekli bilgileri sağlama durumunu kontrol etmeleri istenmiştir. Görüşme başlangıcında çalışma grubuna görüşme ile ilgili genel bilgiler hatırlatılmıştır. Görüşmeler yaklaşık 20 dakika ile 45 dakika arasında değişen sürelerde yapılmış ve yazılı olarak kayıt altına alınmıştır. Çalışma grubunun sorulara verdiği cevaplar doğrultusunda 5 boyut altında 43 maddeden oluşan "Şiir okuma performansını değerlendirme formu" ortaya çıkmıştır (bk. Ek:1).

Şiir okuma performansının değerlendirilmesi için araştırmada görüş alınan çalışma grubu aşağıdaki tabloda belirtilmiştir. Görüşmenin gizliliği ve özel yapısını korumak amacıyla unvanlar kısaltmalarla kullanılmıştır. Bu kısaltmaların açılımı aşağıdaki tabloda verilmektedir (Tablo 1). Ayrıca görüşmede sorulan sorulara öğretmen adaylarının samimi düşüncelerini aktarmaları için gerekli ortam sağlanmaya çalışılmıştır.

Tablo 1: Çalışma grubunun mesleki dağılımlarının araştırmada kullanılacak kısaltmaları Bölümler (f) Araştırmada kullanılacak unvan kısaltması

\begin{tabular}{ccc}
\hline Öğretim Üyesi & 2 & ÖÜ1-ÖÜ2 \\
Türkçe Öğretmeni & 7 & TÖ1-TÖ2-TÖ3... \\
Müzik Öğretmeni & 2 & MÖ1,MÖ2 \\
Sınıf Öğretmeni & 5 & SÖ1-SÖ2-SÖ3... \\
Türk Dili Edebiyatı Öğretmeni & 2 & TDE1-TDE2 \\
Yüksek Lisans Öğrencisi & 3 & YLÖ1-YLÖ2-YLÖ3 \\
Türkçe Öğretmeni Adayı & 5 & TÖA1-TÖA2-TÖA3... \\
\hline Toplam & 26 & \\
\hline
\end{tabular}

Çalışmada aşă̆ıdaki sorulardan faydalanılmıştır:

1. Şiirin iyi okunması için ses ile ilgili nelere dikkat edersiniz? Ses, iyi şiir okunabilmesinde sizce ne kadar önemlidir, niçin?

2. Şiirin iyi okunması için beden dili ile ilgili nelere dikkat edersiniz? Beden dili, iyi şiir okunabilmesinde sizce ne kadar önemlidir, niçin?

3. Şiirin iyi okunması için duygu ile ilgili nelere dikkat edersiniz? Duygu, iyi şiir okunabilmesinde sizce ne kadar önemlidir, niçin?

4. Şiirin iyi okunması için dinleyici ile ilgili nelere dikkat edersiniz? Dinleyici, iyi şiir okunabilmesinde sizce ne kadar önemlidir, niçin?

5. İyi bir şiir okunurken ortam ile ilgili nelere dikkat edersiniz? Ortam, iyi şiir okunabilmesinde sizce ne kadar önemlidir, niçin? 


\section{Verilerin Analizi}

Verilerin analizinde içerik analizi tekniğinden faydalanılmıştır. İçerik analizi yönteminde birbirine benzeyen veriler belirli kavramlar ve temalar çerçevesinde bir araya getirilmekte ve okuyucunun anlayabileceği biçimde düzenlenerek yorumlanmaktadır (Yıldırım ve Şimşek, 2011:227).

Bu çalışma için genel bir çerçeve içinde yapılan kodlama tercih edilmiştir. Bunun için hem daha önceden belirlenmiş kavramlara göre kodlama yapılmış hem de verilerden çıkarılan kavramlara göre kodlama yapılmış, iki tür kodlama biçimi birleştirilmiştir. Yani önce genel bir kavramsal yapı oluşturulmuş ancak ortaya çıkan yeni kodlar listeye dâhil edilmiştir.

Daha sonra veriler belirlenen temalar altında sınıflandırılarak okuyucu için anlamlı bir hale getirilmiştir. Kategorileştirme işlemi araştırmacılar tarafından tekrarlı olarak yapılmıştır. Böylece araştırmanın problemine ve amacına bağlı kalınarak, gereksiz görülenler çıkarılmıştır. Araştırmacılar çalışmanın gerekli aşamalarında, uzman görüşüne başvurmuştur. Veriler kodlara ve temalara göre düzenlenip tanımlanmıştır.

\section{Geçerlik ve Güvenirlik:}

Nitel araştırmada geçerlik, araştırma bulguların doğruluğunu; güvenilirlik ise tekrarlanabilirliğini esas alır (Yıldırm \& Şimşek, 2011, s. 255). Araştırmanın geçerlik ve güvenirliğini artırmak amacıyla birtakım tedbirler alınmıştır.

Araştırmanın iç geçerliğini sağlamak amacıyla alanyazın taraması yapılmış ve araştırmanın konusu ile benzerlik gösteren çalışmalardan faydalanılmıştır. Ayrıca kategoriler ilgili kodları kapsayacak şekilde oluşturulmuştur. Araştırmanın dış geçerliliğini yani aktarılabilirliğini artırmak için araştırma metodolojisi ve bu süreçte yapılanlar ayrıntılı olarak anlatılmıştır.

Araştırmanın iç güvenirliğini (tutarlığını) artırmak için araştırmacılar tarafından yapılan kodlamalar uzman iki araştırmacı tarafından da kontrol edilmiş ve değerlendirilmiştir. Araştırmanın dış güvenirliğini (teyit edilebilirliğini) artırmak için araştırma süreci ayrıntılı biçimde tanımlanmıştır. Ayrıca elde edilen veri seti ve kodlar başka araştırmacıların incelemesine imkân verecek şekilde korunmaktadır.

\section{Bulgular ve Yorum}

Bu bölümde araştırma bulguları katılımcıların görüşlerinden doğrudan alıntılar yapılarak yorumlanmaya çalışılmıştır. 
Ses ile ilgili bulgular

Şiirin iyi okunması için ses ile ilgili nelere dikkat edersiniz? Ses, iyi şiir okunabilmesinde sizce ne kadar önemlidir, niçin? sorularına karşılık katılımcıların dile getirdiği görüşler, frekansları ile birlikte Tablo 2'de verilmiştir.

Tablo 2: Şiirin iyi okunabilmesinde sesin rolü ile ilgili görüşler

\begin{tabular}{ll}
\hline Görüşler & $(\mathrm{f})$ \\
\hline Sesin açık, net ve anlaşılır olması & 12 \\
Sesinin frekansını (yükseltme-alçaltma) iyi ayarlaması & 11 \\
Ses renginin güzelliğini kullanması & 9 \\
Kelimeleri doğru telaffuz ederek okuması & 9 \\
Vurgu ve tonlamaya dikkat ederek okuması & 8 \\
Noktalamaya dikkat ederek okuması & 8 \\
Gereksiz sesler çıkarmaktan kaçınması & 7 \\
Durakları gerektiği gibi kullanması & 6 \\
Şiir okurken nefesini (diyaframı) iyi ayarlaması & 5 \\
Standart Türkçe (İstanbul Türkçesi) ile okuması & 5 \\
İmlaya dikkat ederek okuması & 4 \\
Seslendirmesinin anlaşılacak hızda olması & 4 \\
Ulamaları gerektiği gibi kullanması & 4 \\
Yapmacıklıktan, taklit ve özentiden uzak bir sesle şiir okuması & 3 \\
Şiirin ezgisine dikkat ederek okuması & 2 \\
Sesinin herkes tarafından duyulur olması & 2 \\
Sesinin tınısını şiirin anlamına göre belirlemesi & 2 \\
\hline
\end{tabular}

*Bazı öğretmen adayları birden fazla görüş bildirmiştir.

Tablo 2'de de görüldüğü gibi ses ile ilgili toplam 101 ifadede bulunulduğu görülmektedir. Ses ile ilgili sesin açık, net ve anlaşılır olması, sesin herkes tarafından duyulur olması, seslendirmenin anlaşılacak hızda olması, sesin frekansının (yükseltme-alçaltma) iyi ayarlanabilmesi, ses renginin güzelliğinin kullanılabilmesi, kelimelerin doğru telaffuz edilerek okunabilmesi, vurgu ve tonlamaya dikkat edilerek okunabilmesi, noktalamaya dikkat edilerek okunabilmesi, gereksiz sesler çıkarmaktan kaçınılması, durakların gerektiği gibi kullanılabilmesi, şiir okurken nefesin (diyaframın) iyi ayarlanabilmesi, standart Türkçe (İstanbul Türkçesi) ile okunabilmesi, imlaya dikkat edilerek okunabilmesi, seslendirmenin anlaşılacak hızda yapılabilmesi, ulamaların gerektiği gibi kullanılabilmesi, yapmacıklıktan, taklit ve özentiden uzak bir sesle şiir okunabilmesi, şiirin ezgisine dikkat ederek okunabilmesi, sesinin herkes tarafından duyulur olabilmesi, sesinin tınısının şiirin anlamına göre belirlenebilmesi maddeleri tespit edilmiştir. Şiirin iyi okunması için ses ile ilgili bazı katılımcıların görüşleri ise şu şekildedir:

ÖÜ1:"Şiir okunurken ses açık, net ve anlaşılır olmalı, vurgu ve tonlamaya dikkat edilmeli, imla kurallarına uyulmalıdır." YÖ1: "Şiir okurken nefes iyi ayarlanmalıdır. Kelimeler doğru telaffuz edilmelidir. Ulamalar gerektiği gibi kullanılmalıdır." Mö1:"Şiir okumada nefes çok önemlidir. Ayrıca duraklamalar ne fazla olmalı ne de gereğinden az olmalı, gerektiği şekilde olmalıdır." Mö2: "Ses iyi 
ayarlanmalı, noktalamaya dikkat edilmeli, sesin alçalıp yükselmesi gereken yerleri iyi ayarlanmalı, şiirin ezgisine dikkat edilmelidir. Bunlardan başka önemli bir husus da ses renginin güzelliğinin kullanılabilmesidir” sö1: "Iyi şiir okumada ses ile ilgili en önemli unsur, seslendirmedeki hızın iyi ayarlanmasıdır. Çünkü çok hızlı okunan şiir anlaşılmayacak ya da gereğinden fazla yavaş okunan şiir de sıkıc hale gelebilecektir."

\section{Beden dili ile ilgili bulgular}

Şiirin iyi okunması için beden dili ile ilgili nelere dikkat edersiniz? Beden dili, iyi şiir okunabilmesinde sizce ne kadar önemlidir, niçin? sorularına karşılık katılımcıların dile getirdiği görüşler, frekansları ile birlikte Tablo 3'te verilmiştir.

Tablo 3: Şiirin iyi okunabilmesinde beden dilinin rolü ile ilgili görüşler

\begin{tabular}{ll}
\hline Görüşler & $(\mathrm{f})$ \\
\hline Jestlerini (beden hareketlerini) yerinde kullanması & 11 \\
Mimiklerini (yüz ifadelerini) yerinde kullanması & 10 \\
Dış görünüşüne dikkat etmesi & 5 \\
Duruşunun dik ve kendinden emin olması & 5 \\
Beden diliyle şiirin önüne geçmemesi & 2 \\
\hline
\end{tabular}

Tablo 3 incelendiğinde beden dili ile ilgili toplam 33 ifadede bulunulduğu görülmektedir. Beden dili ile ilgili jestlerini (beden hareketlerini) yerinde kullanabilmesi, mimiklerini (yüz ifadelerini) yerinde kullanabilmesi, dış görünüşüne dikkat etmesi, duruşunun dik ve kendinden emin olması, beden diliyle şiirin önüne geçmemesi maddeleri tespit edilmiştir. Şiirin iyi okunması için beden dili ile ilgili bazı katılımcıların verdiği cevaplar şu şekildedir:

TDE1:"Beden dili şiir okumada çok önemlidir. Çünkü dinleyici için, şiiri sadece sözel olarak okumak yetmiyor; şiiri okuyanın el-yüz hareketleri de şiire katkı sağlıyor." TDE2:"Şiir okurken beden dili şiiri gölgede bırakmamalı sadece desteklemelidir. Beden dilinin abartılması durumunda dinleyicinin bütün dikkati hareketlere yoğunlaşıp, şiir arka planda kalabilmektedir." Yö2:"Bence jest ve mimiklerin doğru kullanılması gerekir." sö4:"Şiir okuyucusunun dış görünüşü de çok önemlidir, çünkü saç, sakal, giysi gibi şeyler dinleyicinin dikkatini çekmektedir."

\section{Duygu ile ilgili bulgular}

Şiirin iyi okunması için duygu ile ilgili nelere dikkat edersiniz? Duygu, iyi şiir okunabilmesinde sizce ne kadar önemlidir, niçin? sorularına karşılık katılımcıların dile getirdiği görüşler, frekansları ile birlikte Tablo 4'te verilmiştir. 
Tablo 4: Şiirin iyi okunabilmesinde duygunun rolü ile ilgili görüşler

\begin{tabular}{ll}
\hline Görüşler & (f) \\
\hline Şiirin ruhunu yansıtması & 11 \\
Şiirdeki duyguyu verebilmek için ezberden okuması & 9 \\
Şiiri hissederek okuması & 8 \\
Şiiri okurken heyecan duymaması & 5 \\
Şiiri taklitten uzak okuması & 4 \\
Psikolojik durumunun şiir okuyuşunu etkilememesi & $\mathbf{4}$ \\
\hline
\end{tabular}

Tablo 4 incelendiğinde katılımcıların şiirde duygunun rolü ile ilgili toplam 41 ifadede bulunulduğu görülmektedir. Duygu ile ilgili şiiri okurken şiirin duygusunu yansıtabilmesi, şiirdeki duyguyu verebilmek için ezberden okuması, şiiri hissederek okuması, şiiri okurken heyecan duyabilmesi, şiiri taklitten uzak okuması, okuyuşunu o an ki psikolojik durumunun etkilememesi maddeleri tespit edilmiştir. Şiirin iyi okunmasında duygu ile ilgili bazı katılımcıların ifadeleri şöyledir:

Mö2: "Bence şiir okunurken duygu çok çok önemlidir. Çünkü okuduğu şiire gereken ruh verilmediğinde o şiir, şiir olmaktan çıkıp düz metin okuma havası vermektedir. Zaten şiiri düz metinden asıl ayıran da duygulu okumak değil midir?" Yö1: "Kişinin o andaki psikolojik durumu şiir okuyuşunu etkilememelidir, aksi halde şiire gereken duyguyu veremez. Sadece içinde bulunduğu durumu yansıtır." TÖA4: "Şiir okurken kişinin, başkalarını taklitten kesinlikle uzak durması gerekir. Kendi olmadıkça şiire gereken duyguyu veremez." TÖA5: "Şiir hissederek, sanki okunanlar yaşanıyormuş gibi okunmalı, dinleyiciye bu hissettirilmelidir. Örneğin, katıldığım bir şiir dinletisinde Istiklâl Marşı'nı okuyan öğrencilerden birinin hissederek okuduğuna şahit oldum, bende o izlenimi bıraktı, beni de duygulandırdı." sö1:"Bence şiirin ezberden ya da yüzünden okunması duyguyu vermede çok önemlidir."

Dinleyici ile ilgili bulgular

Şiirin iyi okunması için dinleyici ile ilgili nelere dikkat edersiniz? Dinleyici, iyi şiir okunabilmesinde sizce ne kadar önemlidir, niçin? sorularına karşılık katılımcıların dile getirdiği görüşler, frekansları ile birlikte Tablo 5'te verilmiştir.

Tablo 5: Şiirin iyi okunabilmesinde dinleyicinin rolü ile ilgili görüşler

\begin{tabular}{ll}
\hline Görüşler & (f) \\
\hline Dinleyicilerle göz teması kurması & 8 \\
Dinleyicilere hâkim olması & 7 \\
Dinleyicilerin o anki psikolojik durumundan etkilenmemesi & 5 \\
Dinleyicilerin cinsiyetinden etkilenmemesi & 2 \\
Dinleyicilerin yaş ortalamasından etkilenmemesi & 2 \\
Dinleyicilerin statüsünden etkilenmemesi & 2 \\
Dinleyicileri etkileme, duygulandırma kaygısına girmemesi & 2 \\
\hline
\end{tabular}


Tablo 5 incelendiğinde, şiirin iyi okunması için dinleyici ile ilgili toplam 28 ifade bulunmaktadır. Dinleyici ile ilgili, dinleyicilerle göz teması kurması, dinleyicilere hâkim olması, dinleyicilerin $\mathrm{o}$ an $\mathrm{ki}$ psikolojik durumundan etkilenmemesi, dinleyicilerin cinsiyetinden etkilenmemesi, dinleyicilerin yaş ortalamasından etkilenmemesi, dinleyicilerin statüsünden etkilenmemesi, dinleyicileri etkileme, duygulandırma kaygısına girmemesi maddeleri tespit edilmiştir. Şiirin iyi okunması için dinleyici ile ilgili bazı katılımcıların verdiği cevaplar ise şu şekildedir:

TÖA3: "Dinleyici iyi şiir okunabilmesinde önemli bir faktördür. Çünkü şiir okumada ilk akla gelen okuyucu ve dinleyicidir." TÖA1: "Şiir okunurken dinleyici ile göz temasını iyi kurmak gerekir. Hatırlıyorum da öğrencilik yıllarımda şiir okurken hep yere bakardım. Çünkü utanırdım. Bunun ne kadar komik olduğunu sonraları anladım. Ve şiir okurken dinleyiciye bakmak ama bakarken de ölçülü bakmak gerektiğini düşünüyorum." Tö7: "Şiiri okurken dinleyiciyi etkileme kaygısına girilmemelidir bence. O kaygı ile okuma kusurları ortaya çıkabilir ve şiir okurken verilmesi gereken duygu arka planda kalabilir." SÖ2: "Ben şiir okurken dinleyicilerin cinsiyetinden çok etkilenirdim. Özellikle bayanların olduğu ortamda iyi şiir okuyamazdım. Onun için iyi şiir okumak için dinleyicinin cinsiyetinden etkilenmemek çok önemli."

\section{Ortam ile ilgili bulgular}

Şiirin iyi okunması için ortam ile ilgili nelere dikkat edersiniz? Ortam, iyi şiir okunabilmesinde sizce ne kadar önemlidir, niçin? sorularına karşılık katılımcıların dile getirdiği görüşler, frekansları ile birlikte Tablo 6'da verilmiştir.

Tablo 6: Şiirin iyi okunabilmesinde ortamın rolü ile ilgili görüşler

\begin{tabular}{lc}
\hline Görüşler & (f) \\
\hline Ortamdaki sahneye hâkim olması & 9 \\
Dinleyicisinin ilgisini canlı tutmak için sahneyi iyi kullanması & 4 \\
Ortamın fiziki durumundan (ışık, ısı, havalandırma, açık, kapalı vs.) etkilenmemesi & 4 \\
Sahnenin boyutundan etkilenmemesi & 3 \\
Şiir okurken müzikten yararlanması & 3 \\
Şiir okurken görsellerden yararlanması & 3 \\
Dış ortamdan gelen seslerin dikkatini dağıtmaması & 2 \\
Ortamın atmosferine uyum sağlaması & 2 \\
\hline
\end{tabular}

Tablo 6 incelendiğinde şiirin iyi okunmasında ortam ile ilgili toplam 30 ifade bulunmaktadır. Ortamla ilgili, ortamdaki sahneye hâkim olması, dinleyicisinin ilgisini canlı tutmak için sahneyi iyi kullanması, ortamın fiziki durumundan (ışı, ısı, havalandırma, açık, kapalı vs.) etkilenmemesi, sahnenin boyutundan etkilenmemesi, şiir okurken müzikten yararlanması, şiir okurken görsellerden yararlanması, dış ortamdan gelen seslerin dikkatini dağıtmaması, ortamın atmosferine uyum sağlaması maddeleri tespit edilmiştir. Şiirin iyi okunması için ortam ile ilgili bazı katılımcıların verdiği cevaplar şu şekildedir: 
öü1: "Ortamın durumu şiir okuyucusunu ciddi anlamda etkilemektedir. Işık, ISI, havalandırmanın yetersiz ya da yeterinden fazla olması şiir okuyucusunu olumsuz etkileyeceği gibi yeterli olması da olumlu etkiler." TDE1: "Şiir okurken ortama iyi hâkim olunmalı, dinleyiciyi canlı tutmak için sahnede sabit bir yerde değil, değişik yerlerde durarak okumalıdır." Tö6: "Sahnenin büyük ya da küçük olması şiirin iyi okunmasını etkileyebilir çünkü bazı kişiler sahne küçük olduğu için dinleyici ile çok yakınlaştık korkusuna kapılabilir."

\section{Tartışma ve Sonuç}

Şiir okumanın insana kazandırdığı değerler yeni değildir ancak güzel şiir okumanın değerlendirilmesi, akademik olarak üzerinde henüz çok durulmamış bir konudur. Araştırma bulgularında da ortaya konulduğu gibi şiir okumayı değerlendirebilmek ve şiir okumada standarda gidebilmek için görüşlerden hareketle bir değerlendirme formu sunulabileceği görülmektedir. Çağdaş değerlendirme yöntemlerinden biri olan performans değerlendirme; şiir okumayı değerlendirecek kişilere bu konuda bilimsel bir kaynakla, objektif bir değerlendirme yapmalarına olanak sağlamaktadır. Çakan (2004)'a göre ilköğretim ve ortaöğretimde görev yapan öğretmenlerin büyük bir kısmı ölçme değerlendirme konusunda kendilerini yetersiz ya da eksik bulmaktadır. Çalışma neticesinde ortaya konulan performans değerlendirme formunun bu eksikliğin giderilmesine bir nebze yardımcı olacağı düşünülmektedir.

Yapılan görüşmelerden ulaşılan sonuçlar doğrultusunda ses, beden dili, duygu, dinleyici ve ortam başlıkları altında kırk üç madde belirlenmiştir. Okunan şiirin etkileyiciliğinin subjektifliği, çalışmada ortaya konan kriterleri ebette ki sorgulanabilir kılmaktadır. Belirlenen tüm ölçütlere uygun şekilde bir şiir seslendirildiğinde dahi dinleyen kişiler arasında beğenme-beğenmeme konusunda bir farklılık olacaktır ki bu da insanın doğasında da şiirin doğasında da vardır. Burada önemli olan, belirlenen kriterlerin şiir okumanın değerlendirilmesinde azami objektifliğe ulaşması olmalıdır.

Çalışmada ulaşılan bazı sonuçlar şöyledir:

Çalışmada iyi şiir okumada öncelikle akla gelenin ses olduğu görülmektedir. Taşer (2012)'in araştırmasına göre konuşmayı oluşturan etmenlerin başında ses gelmektedir. Ünalan (1996) konuşma hızını iyi düzenleyememenin akıcılığı bozduğunu ifade etmiştir. Yani seslendirmenin anlaşılacak hızda olması, sesin açık, net ve anlaşılır olması iyi şiir okumada gereken kriterler arasındadır.

Töreyin (2008) konuşmada dilin anlaşılırlığı, kelimelerdeki vurgu ile cümlelerin ritmik ve melodik olmasının öneminden bahsetmektedir. Şarkı söyleme ve özellikle şan eğitiminin, müziğin etkisini sesin etkileme gücü ile sergilemenin, konuşma eğitiminde yerini söyleyişe- diksiyona (telaffuza) bıraktığı ifade etmektedir. Topçuoğlu ve Özden (2012) de nitelikli bir konuşmada konuşmacının sesini ne denli iyi ayarlarsa, o denli iyi bir konuşmacı olup toplumda yer edinebileceğinden bahsetmektedirler. 
Güneş (2013:121) “konuşmada ses hacmi, ses perdesi, tonlama, kalite, hız, lehçe ve biçim gibi bazı öğelere dikkat edilmesi" gerekliliğini belirtmiştir. Gürzap (2009)'a göre ise, güzel ve etkileyici bir ses, konuşmayı desteklemekte, konuşmanın etkisini artırmaktadır. Ses renginin güzelliği ifadesi de 9 katılımcı tarafından kullanılmış, bu yorum desteklenmiştir. Araştırmamızdaki sesin açık, net ve anlaşılır olması (f12), sesin frekansının iyi ayarlanması (f11), ses renginin güzelliği (f9) ile ilgili bulgular bu görüşlere paraleldirler.

Çalışmada beden dili kullanımıyla ilgili daha çok jestlerin (f11) ve mimiklerin yerinde kullanması (f10) dikkati çekmektedir. Çelik (1998: 59) yapılan araştırmalarda insan yüzünün 250 bin değişik ifadeyi anlatabildiğini belirtmektedir. Jest ve mimiklerin doğal bir biçimde yapıldığında, konuşmanın canlılık kazandığı, sözcükler ve cümlelerin renklendiğini ifade etmektedir. Özellikle vurgulanmak istenen önemli noktalara dinleyicilerin dikkatlerinin çekilmiş olduğu, düşünce ve duyguların vurgulanmasında yapılacak abartılı hareketlerin ise yarardan çok zarar getirdiği, dinleyicinin, söylenenlere değil de söyleyene dikkat etmeye başladığını eklemektedir.

Baltaş ve Batlaş (2001)'ın çalışmasına göre insanların; duygularını, düşüncelerini, isteklerini, ihtiyaçlarını ve ruhsal zenginliklerini başka insanlarla paylaşırken beden dillerini kullandıkları belirtilmektedir. Altıntaş ve Çamur (2005) çalışmalarında, sözcüklerin kullanımının yanı sıra bakış, duruş, hareket, ses tonu ve kıyafet aracılığıyla sürekli mesaj göndermenin söz konusu olduğunu, şiir okuma performansını değerlendirmede beden dilinin etkisinin oldukça fazla olduğunu ifade etmektedirler. Bu yorum da çalışmamızın neticesinde ortaya çıkan beden dilinin önemiyle aynı doğrultudadır. Ayrıca daha önce yapılan birçok araştırmada da (Açıl, 2005; Ergin ve Birol, 2000; Altıntaş ve Çamur, 2005) beden dilinin önemi vurgulanmıştır.

Beden dili temasının içerisinde yer alan dış görünüşün önemini Açıl (2005), giyim-kuşamın, bireyin sözleri ve bedeni kadar, beğenilerini, o anki ruhsal durumunu, karşısındakilere verdiği önemi ve değeri yansıttığı şeklinde yorumlamaktadır. Yine Altıntaş ve Çamur (2005) yerine ve zamanına uygun olmayan kıyafetlerin önemli mesajların hafife alınmasına ve yanlış algılanmasına yol açtığını ifade etmektedirler. Şahin ve Aydın (2013) kıyafet renginin, kişinin estetik algısını, sahip olduğu iç dünyasını yansıttığını belirtmekte ve bunun yanı sıra bir araya geldiği insanlara verdiği önemi de ortaya koyduğunu anlatarak çalışmamızı desteklemektedirler.

Şiir duyguyla iç içe olan bir kavramdır. Zaten şiir, duygu ve düşüncelerin sözle ya da yazıyla anlatılması şeklinde tanımlanmaktadır. Yani duygu ve şiiri ayrı ayrı düşünmek mümkün değildir. Bu sebeple şiirde var olan duygunun, ruhun aktarılması önem kazanmaktadır. Maaç (2008) konuşmanın, içinde biraz heyecan ve telaş taşımasının, konuşmayı daha renklendirdiğini ifade etmekte; şiir okumada ve dinlemede duygunun çok önemli olduğunu vurgulamaktadır. Araştırmamıza göre duygusuz şiir okunmayacağı gibi duygusuz şiir dinlenemeyeceği sonucuna da varılmıştır. 
Şiir de okuyucu kadar dinleyicinin de önemli rolü vardır. Güneş (2012:22) "anlama sürecinin en önemli bileşenin dinleyici" olduğunu aktarmaktadır. Taşer (2012), gönderen/konuşanın etken, alıcının/dinleyicinin edilgen bir rol oynadığı sonucunu çıkarmanın yanlış olduğunu ifade etmektedir. Özbay (2009) ise dinleme yoluyla öğrencilerin iletişim kurma, öğrenme ve zihinsel yapısını geliştirmesinin kolay olduğunu belirtmektedir.

Topçuoğlu ve Özden (2012) gözlerin iletişimin temel unsurlarından olduğunu, konuşurken hatta konuşmadan da gözlerle pek çok şey ifade edilebileceğini ve konuşurken göz ile dinleyici arasındaki temasın kopartılmaması gerektiğini belirtmektedirler. Bunun aynı zamanda dinleyiciye hâkim olmaya da yardımcı olacak bir kural olduğu belirtilmektedir.

Akkaya (2012) psikolojik nedenlerden kaynaklanan konuşma sorunlarına ilişkin öğretmen adaylarının görüşleri ile ilgili yaptığı çalışmasında topluluk karşısında konuşamama nedenleri ile ilgili rahat hissetmeme, çekinme gibi sebeplerin yanında tanınmayan insanlar karşısında heyecanlanma, karşı cinsle konuşmama, özgüven eksikliği, göz teması kuramama, önemli kişilerin karşısında konuşamama gibi nedenleri de ifade etmiştir. Ayrıca Topçuoğlu ve Degeç (2012) de konuşma becerisi etkinliklerinde öğretmenlerin en çok arkadaşlarından utanma ve heyecan sorunuyla karşılaştıklarından bahsetmektedirler. Bu sonuçlar da çalışmada yer alan dinleyici ile ilgili bulgularla paralellik göstermektedir.

Ortamın olumlu yönde düzenlenmesi kaliteli dinleme sağlamak için gereklidir. Kavcar, Oğuzkan ve Sever (1995)'in araştırmasında, dinlemenin gerçekleşeceği ortamın, öncelikle sağlıklı olması ve işitmeye engel olmaması ifade edilmiştir. Ayrıca şiir okurken müzikten yararlanılması, Albuz (1997)'un araştırmasında sözlü bir müzik yapıtında, sözlerin kuvvetli ve zayıf heceleriyle, ölçünün kuvvetli ve zayıf zamanları arasındaki uygunluğun sağlanması ile müziğin sözlere veya sözlerin müziğe uygulanması fikirlerini desteklemektedir.

Yapılan bu çalışmada, şiir okuma performansını değerlendirmeyi tasarlamak ve şiir okumada bir standart oluşturmak istenilmiştir. Konu ile ilgili mesleklerde çalışan kişilerle görüşülmüş ve şiiri güzel okuyabilmenin nelerle alakalı olduğu üzerine fikirlerine başvurulmuştur.

Yapılan görüşmeler incelendiğinde şiir okuma ile ilgili belirlenen "Ses, Beden Dili, Duygu, Dinleyici ve Ortam" gibi beş temel boyutun 43 alt maddesi oluşturulmuştur. Konu ile ilgili kişilerle yapılan görüşme sonuçları da dikkate alındığında, çalışmada, şiiri güzel okuyabilmenin bir standardı olabileceği ve bu standardın analitik olarak bir değerlendirme cetveline yerleştirilebileceği gösterilmiştir. Öğretmenlerin, bu alanda çalışan akademisyenlerin, şiir okuma gruplarının ve şiir alanıyla ilgili grupların bu çalışmadan faydalanabilecekleri düşünülmektedir.

\section{Öneriler}

Bu çalışmanın alanda bundan sonra şiir okumayı değerlendirme ile ilgili yapılan çalışmalarda yol gösterici olabileceği düşünülmektedir. Bu çalışmada kullanılan form önerisi ileriki çalışmalarda, 
ölçek geliştirme yaklaşımlarından faydalanılıp geçerlik ve güvenirlik çalışmaları yapılarak şiir okumayı değerlendirme ölçeği haline getirilebilir.

\section{Kaynakça}

Açıl, M. (2005). Öğretmenin beden dili. İstanbul: Armoni Gelişim Yayıncılık.

Akkaya, A. (2012). Öğretmen adaylarının konuşma sorunlarına ilişkin görüşleri. Mustafa Kemal Üniversitesi Sosyal Bilimler Enstitüsü Dergisi, 9(20), 405-420.

Altıntaş, E. ve Çamur, D. (2005). Beden dili. Sözsüz iletişim. İstanbul: Aktüel Yayınları.

Albuz, A. (1997) "Eğitim müziği amaçlı sözlü müzik eserlerinde dilin kullanımı ve prozodi üzerine görüşler", Müzik Eğitimi Sempozyum Bildirisi. Ankara Üniversitesi Eğitim Bilimleri Fakültesi Dergisi.

Bahar, M., Nartgün, Z., Durmuş, S. ve Bıçak, B. (2008). Geleneksel-alternatif ölçme ve değerlendirme öğretmen kitabı. Ankara: Pegem Akademi Yayınları.

Baltaş, Z. ve Baltaş, A. (2001). Beden dili. İstanbul: Remzi Kitabevi.

Bayram, L. (2006). Geleneksel performans değerlendirme yöntemlerine yeni bir alternatif: 360 derece performans değerlendirme. Ankara Üniversitesi Eğitim Bilimleri Enstitüsü, Sayıştay Dergisi, 62,47.

Büyüköztürk, Ş., Çakmak, E., Akgün, Ö., Karadeniz, ş. ve Demirel, F. (2010). Bilimsel araştırma yöntemleri (5.Baskı). Ankara: Pegem A Yayıncılık.

Çakan, M. (2004). "Öğretmenlerin ölçme-değerlendirme uygulamaları ve yeterlik düzeyleri: ilk ve ortaöğretim", 37, 99-114.

Çelik, Z. Ö., (1998). Konuşmayı etkileyen ögeler. Pilancı H (Ed.) Sözlü ve yazııı anlatım. Eskişehir: Anadolu Üniversitesi, Açıköğretim Fakültesi Yayınları. (59-71). Ankara: Gazi Kitabevi.

Ergin, A. ve Birol, C.(2000). Eğitimde iletişim. Ankara: Anı Yayıncılık.

Ekiz, D. (2003). Eğitimde araştırma yöntem ve metotlarına giriş. Ankara: Anı Yayıncılık.

Güneş, F. (2012). Öğrencilerin Sözlü anlama becerilerini geliştirme. Türkiye Sosyal Araştırmalar Dergisi, 16(2), 10-30

Güneş, F. (2013). Türkçe öğretim, yaklaşımlar ve modeller. Ankara: Pegem Akademi

Gürzap, C. (2009). Söz söyleme ve diksiyon (13.Basım), İstanbul: Remzi Kitabevi.

Luft, J.A. (1999). Rubrics: Design and use in science teacher education. journal of science teacher education,10 (2),107-121.

Kaplan, M. (2003). Şiir tahlilleri 1 Tanzimat'tan Cumhuriyet'e. İstanbul: Dergâh Yayınları.

Karasar, N. (2010). Bilimsel araştırma yöntemi (21. Baskı). Ankara: Nobel Yayın Dağııım.

Kavcar, C. ve Oğuzkan, F. (1999). Yazılı ve sözlü anlatım, Ankara: Anı Yayınları.

Kaya, M. (2013). Okuma yazma öğretiminde şiir. Dil ve Edebiyat Dergisi, 10(1), 49-96.

Kavcar, C., Oğuzkan, F., Sever, S. (1995). Türkçe ögretimi, Ankara: Engin Yayınevi.

Kıbrıs, i. (2000). Uygulamalı çocuk edebiyatı. Ankara: Eylül Kitap ve Yayınevi.

Kıbrıs, i. (2008). Okuma ve yazma çalışmalarında şiir etkinliklerinden nasıl yararlanılabilir? Abant izzet Baysal Üniversitesi Eğitim Fakültesi Dergisi, 8(1), 53-66.

Kuş, E. (2003). Sosyal bilimlerde araştırma teknikleri nitel mi, nicel mi?. Ankara: Anı Yayıncılık. 
MEB (2005). ilköğretim Türkçe dersi öğretim programı ve kılavuzu (6,7,8. Sınıflar), Ankara.

Özbay, M. (2007). Türkçe özel öğretim yöntemleri II, Ankara: Öncü Yayınları

Özbay, M. (2009). Bir dil becerisi olarak dinleme eğitimi, Ankara: Öncü Kitap.

Özçelik, D. (2010). Ölçme ve değerlendirme. Ankara: Pegem Akademi Yayınları

Sezer, S. (2005). Öğrencinin akademik başarısının belirlenmesinde tamamlayıcı değerlendirme aracı olarak rubrik kullanımı üzerinde bir araştırma. Pamukkale Üniversitesi Eğitim Fakültesi Dergisi, 15, 61-69.

Şahin, A. ve Aydın, G. (2013). "Konuşmada Beden Dili”, Konuşma Eğitimi (Ed: Aziz Kılınç ve Abdullah Şahin). Ankara: Pegem A Akademi.

Taşer, S. (2012). Konuşma Eğitimi. İstanbul: Pegasus Yayınevi.

Tavşancıl, E. ve Aslan, E. (2001). İçerik Analizi ve Uygulama Örnekleri. İstanbul: Epsilon Yayıncılık.

Topçuoğlu F. ve Özden M. (2012). Diksiyon ve Konuşma Eğitimi. Ankara: Pegem Akademi.

Topçuoğlu F ve Degeç, H. (2012). Öğretmen Görüşlerine Göre Konuşma Eğitiminde Karşılaşılan Sorunlar. JASSS, $5(7), 735-750$.

Töreyin, A.M. (2008). Ses Eğitimi Temel Kavramlar- Illkeler- Yöntemler, Ankara: Sözkesen Matbaacılık.

Ünalan, Ş. (1996). Şahsiyet ve Dil illişkisi (Yayınlanmamış Yüksek Lisans Tezi), Gazi Üniversitesi, Sosyal Bilimler Enstitüsü, Ankara.

WEB1: http://ttkb.meb.gov.tr/ adresinden 19.06.2013 tarihinde erişilmiştir.

Yıldırım, A. ve Şimşek, H., (2011). Sosyal bilimlerde nitel araştırma yöntemleri (8. Baskı). Ankara: Seçkin Yayıncilık. 
Şiir Okuma Performansını Değerlendirme ile ilgili Görüşler ve Bir Değerlendirme Formu Önerisi

\begin{tabular}{|c|c|c|c|c|c|}
\hline \multicolumn{3}{|r|}{ ŞiiR OKUMA PERFORMANSINI DEĞERLENDIRME FORMU } & $\begin{array}{l}\overline{\bar{亠}} \\
\overline{ \pm} \\
\stackrel{\nu}{\nu}\end{array}$ & 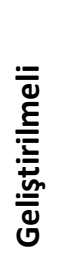 & \multirow[t]{2}{*}{$\begin{array}{l}\frac{N}{\omega} \\
\frac{\omega}{ \pm ँ} \\
\nu\end{array}$} \\
\hline \multirow{17}{*}{ SES } & 1 & Sesin açık, net ve anlaşılır olması & & & \\
\hline & 2 & Sesinin frekansını (yükseltme-alçaltma) iyi ayarlaması & & & \\
\hline & 3 & Ses renginin güzelliğini kullanması & & & \\
\hline & 4 & Kelimeleri doğru telaffuz ederek okuması & & & \\
\hline & 5 & Vurgu ve tonlamaya dikkat ederek okuması & & & \\
\hline & 6 & Noktalamaya dikkat ederek okuması & & & \\
\hline & 7 & Gereksiz sesler çıkarmaktan kaçınması & & & \\
\hline & 8 & Durakları gerektiği gibi kullanması & & & \\
\hline & 9 & Şiir okurken nefesini (diyaframı) iyi ayarlaması & & & \\
\hline & 10 & Standart Türkçe (İstanbul Türkçesi) ile okuması & & & \\
\hline & 11 & İmlaya dikkat ederek okuması & & & \\
\hline & 12 & Seslendirmesinin anlaşılacak hızda olması & & & \\
\hline & 13 & Ulamaları gerektiği gibi kullanması & & & \\
\hline & 14 & Yapmacıklıktan, taklit ve özentiden uzak bir sesle şiir okuması & & & \\
\hline & 15 & Şiirin ezgisine dikkat ederek okuması & & & \\
\hline & 16 & Sesinin herkes tarafindan duyulur olması & & & \\
\hline & 17 & Sesinin tınısını şiirin anlamına göre belirlemesi & & & \\
\hline \multirow{5}{*}{$\begin{array}{c}\text { BEDEN } \\
\text { Díí }\end{array}$} & 18 & Jestlerini (beden hareketlerini) yerinde kullanması & & & \\
\hline & 19 & Mimiklerini (yüz ifadelerini) yerinde kullanması & & & \\
\hline & 20 & Dış görünüşüne dikkat etmesi & & & \\
\hline & 21 & Duruşunun dik ve kendinden emin olması & & & \\
\hline & 22 & Beden diliyle şiirin önüne geçmemesi & & & \\
\hline \multirow{6}{*}{ DUYGU } & 23 & Şiiri okurken şiirin ruhunu yansıtması & & & \\
\hline & 24 & Şiirdeki duyguyu verebilmek için ezberden okuması & & & \\
\hline & 25 & Şiiri hissederek okuması & & & \\
\hline & 26 & Şiiri okurken heyecan duymaması & & & \\
\hline & 27 & Şiiri taklitten uzak okuması & & & \\
\hline & 28 & Psikolojik durumunun şiir okuyuşunu etkilememesi & & & \\
\hline \multirow{7}{*}{ DINLEYici } & 29 & Dinleyicilerle göz teması kurması & & & \\
\hline & 30 & Dinleyicilere hâkim olması & & & \\
\hline & 31 & Dinleyicilerin o an ki psikolojik durumundan etkilenmemesi & & & \\
\hline & 32 & Dinleyicilerin cinsiyetinden etkilenmemesi & & & \\
\hline & 33 & Dinleyicilerin yaş ortalamasından etkilenmemesi & & & \\
\hline & 34 & Dinleyicilerin statüsünden etkilenmemesi & & & \\
\hline & 35 & Dinleyicileri etkileme, duygulandırma kaygısına girmemesi & & & \\
\hline \multirow{8}{*}{ ORTAM } & 36 & Ortamdaki sahneye hâkim olması & & & \\
\hline & 37 & Dinleyicisinin ilgisini canlı tutmak için sahneyi iyi kullanması & & & \\
\hline & 38 & Ortamın fiziki durumundan (ışık, ısı, havalandırma, açık, kapalı vs.) etkilenmemesi & & & \\
\hline & 39 & Sahnenin boyutundan etkilenmemesi & & & \\
\hline & 40 & Şiir okurken müzikten yararlanması & & & \\
\hline & 41 & Şiir okurken görsellerde yararlanması & & & \\
\hline & 42 & Dış ortamdan gelen seslerin dikkatini dağıtmaması & & & \\
\hline & 43 & Ortamın atmosferine uyum sağlaması & & & \\
\hline
\end{tabular}

